\title{
Performance of Anaerobic Bioreactors under Diurnally Cyclic Air Temperatures: A Spectral Analysis Approach to Biogas Production
}

\section{EA Echiegu' 1 AE Ghaly ${ }^{2 *}$ and VV Ramakrishnan ${ }^{2}$}

${ }^{1}$ Department of Agricultural and Bioresources Engineering, University of Nigeria, Nsukka, Enugu State, Nigeria

${ }^{2}$ Department of Process Engineering and Applied Sciences, Dalhousie University, Halifax, Nova Scotia, Canada

\begin{abstract}
The effects of two diurnally cyclic temperature ranges $\left(20-40^{\circ} \mathrm{C}\right.$ and $\left.15-25^{\circ} \mathrm{C}\right)$ and four levels of hydraulic retention times $(25,20,15$, and $10 \mathrm{~d})$ on the performance of anaerobic reactors operated on screened dairy manure were evaluated. The reactor temperature exhibited a lag relative to the chamber air temperature. For the $20-40^{\circ} \mathrm{C}$ temperature cycle, the average lags period at the maximum and minimum chamber temperatures 3.75 and $4.37 \mathrm{~h}$, respectively. For the $15-25^{\circ} \mathrm{C}$ temperature cycle, the average lag periods at maximum and minimum chamber temperatures were 3.61 and $4.34 \mathrm{~h}$, respectively. The effluent solids content were not adversely affected by the reactor diurnally cyclic temperature. The effluent total solids and methane content of the biogas diurnally cyclic patterns were out of phase with the diurnally cyclic pattern of the reactor temperature by about 12 hours under most operating conditions. The reductions in total solids and methane yield were all significantly affected by the diurnal temperature range and hydraulic retention time. Biogas production from a healthy digester operating under a diurnally cyclic temperature environment follow a sinusoidal pattern which can be described by a Fourier equation of the form: $\gamma_{t}=\gamma_{o}+\sum_{n=1}^{\infty}\left[a_{n} \cos (2 \pi n \varphi t)+b_{n} \cos (2 \pi n \varphi t)\right]$. However, where the operating conditions are not favourable, the production followed a sinusoidal pattern which may be embedded in some harmonic and noise.
\end{abstract}

Keywords: Anaerobic reactors; Solids; Volatile fatty acids; Diurnally cyclic Temperature; Biogas; Fourier function; Spectral analysis

\section{Introduction}

Anaerobic digestion is a biological process in which organic materials are decomposed in the absence of free oxygen to yield methane $\left(\mathrm{CH}_{4}\right)$, carbon dioxide $\left(\mathrm{CO}_{2}\right)$ and small quantities of other gases $\left(\mathrm{H}_{2} \mathrm{~S}, \mathrm{~N}_{2}\right.$ and $\left.\mathrm{H}_{2} \mathrm{O}\right)$. The process requires the concerted actions of a symbiotic population of three groups of facultative and obligate anaerobic bacteria. The first group degrade carbohydrates, lipids and proteins into alcohols and long chain fatty acids. The second group produce acetate, carbon dioxide and hydrogen from the fermentation of degraded organic materials. The third group produce methane and carbon dioxide from the fermentation of acetate.

Compared to other biological treatment processes, anaerobic digestion has several advantages including: (a) production of usable biogas that is about $60-80 \%$ methane with a fuel value of $17-23.9 \mathrm{MJ} /$ $\mathrm{m}^{3}$, (b) the digested residue is almost odourless with partially stabilized solids content, (c) the inorganic nutrients are conserved resulting in an enhanced fertilizer value of the digested sludge and (d) pathogenic microorganisms such as Salmonella sp. and Brucella sp. as well as weed seeds are destroyed [1-5]. The latter implies that livestock can be grazed on pastures which have been spread with sludge from the anaerobic digester sooner than would be acceptable if raw manure was used [6]. However, despite these advantages, anaerobic digestion has not enjoyed widespread acceptance among many farmers due to the relative instability of the system resulting from the sensitivity of anaerobic bacteria to changes in environmental conditions [7]. Temperature is considered to be one of the most important environmental parameters affecting the growth and survival of anaerobic microorganisms $[1,4,6,8$ 13]. Diurnally cyclic variation in slurry temperature is a common phenomenon in reactors operated under ambient conditions. Echiegu [14], Ghaly et al. [15] Ghaly and Hattab [6] showed that gas production as well as some other operating indices followed a diurnally cyclic pattern with some lag relative to the diurnally cyclic environmental temperature.
The aim of this study was to investigate the performance of a continuous mix anaerobic reactor operating under diurnally cyclic temperatures by evaluating reductions in the effluents solids and the profile of VFA and biogas. Also, the gas production data was subjected to spectral analysis to determine whether gas production under the above operating condition can be described by a perfectly sinusoid ally periodic function.

\section{Modeling}

Deterministic data is one which can be described by an explicit mathematical relationship; a non-deterministic data cannot. Deterministic data can be classified as periodic or non-periodic. Periodic data and for which the following relationship holds:

$$
Y_{t}=f\left(t+T_{p}\right)
$$

Where:

$Y_{t}$ is the value of the variable at time $t$ in seconds

$T_{p}$ is the period in seconds.

Many periodic data can be described in the form of a sine or cosine wave. Such a data is said to be sinusoidal. A sinusoidal data can be represented by a time dependent function of the following form:

*Corresponding author: Abdel E Ghaly, Process Engineering Department, Dalhousie University, Halifax, Nova Scotia, Canada, Tel: (902) 494-6014 Email: abdel.ghaly@dal.ca

Received December 11, 2013; Accepted December 18, 2013; Published December 27, 2013

Citation: Echiegu EA, Ghaly AE, Ramakrishnan VV (2013) Performance of Anaerobic Bioreactors under Diurnally Cyclic Air Temperatures: A Spectral Analysis Approach to Biogas Production. J Bioprocess Biotech 4: 143 doi: 10.4172/2155-9821.1000143

Copyright: (C) 2013 Echiegu EA, et al. This is an open-access article distributed under the terms of the Creative Commons Attribution License, which permits unrestricted use, distribution, and reproduction in any medium, provided the original author and source are credited. 


$$
Y_{t}=A\left(\cos \omega_{o} t+\phi\right)
$$

Where:

$A$ is the amplitude

$\omega_{\mathrm{o}}$ is the angular frequency $(\mathrm{rad} / \mathrm{s})$

$\varphi$ is the phase angle (rad)

The angular frequency can be expressed as follows:

$\omega_{\mathrm{o}}=2 \pi f$

Where:

$f$ is the frequency in $\mathrm{Hz}=1 / \mathrm{T}_{\mathrm{p}}$

By invoking trigonometric relationships, equation (2) can be expressed as follows:

$$
\left.Y_{t}=a_{1} \cos \left(\omega_{o} t\right)+b_{1} \sin \left(\omega_{o} t\right)\right)
$$

Where:

$$
\begin{aligned}
& a_{1}=A \cos \phi \\
& b_{1}=A \sin \phi
\end{aligned}
$$

Many real life periodic data are not sinusoidal. They are rather complex in nature and can be described as follows:

$$
Y_{t}=\mathrm{f}\left(t+n T_{p}\right)
$$

Where:

\section{$n$ is harmonic number}

More generally, arbitrary periodic functions can be represented by an infinite series of sinusoids of harmonically related frequencies such as Fourier series. A Fourier series representation of a complex periodic data can be written as follows:

$$
\begin{aligned}
& Y_{t}=Y_{0}+\sum_{n=1}^{\infty}\left[a_{n} \cos \left(n \omega_{0} t\right)+b_{n} \sin \left(n \omega_{0} t\right)\right] \\
& \text { Where: }
\end{aligned}
$$

$Y_{o}$ is the mean value of the periodic function

The terms $Y_{o}, a_{n}$ and $b_{n}$ are defined as follows:

$$
\begin{aligned}
& Y_{0}=\frac{1}{T_{p}} \int_{0}^{T_{p}} Y_{t} d t \\
& a_{n}=\frac{2}{T_{p}} \int_{0}^{T_{p}} Y_{t} \cos \left(n \omega_{0} t\right) d t \quad n=0,1,2, \ldots . . \\
& b_{n}=\frac{2}{T_{p}} \int_{0}^{T_{p}} Y_{t} \sin \left(n \omega_{0} t\right) d t \quad n=0,1,2, \ldots . .
\end{aligned}
$$

For equally spaced data with $N$ data points, equation (9) to (11) can be written respectively as follows:

$$
\begin{aligned}
& Y_{0}=\sum_{i=1}^{N} \frac{Y_{t}(t)}{N} \\
& a_{n}=\frac{2}{N} \sum_{i=1}^{N}\left[Y_{t} \cos \left(n \omega_{0} t\right) d t\right] \quad n=0,1,2, \ldots . . \\
& b_{n} \tau=\frac{2}{N} \sum_{i=1}^{N}\left[Y_{t} \sin \left(n \omega_{0} t\right) d t\right] \quad n=0,1,2, \ldots . .
\end{aligned}
$$

Equation (8) indicates that a periodic data can be represented by a static component $Y_{o}$ and an infinite number of sinusoidal components with a fundamental frequency $\omega_{0}$ and harmonic whose frequencies are constant multiples of the fundamental frequency. In periodic data, the sequence repeats, although the repetition may not be exact. To measure the degree of similarity between two successive positions, the sequence would have to be compared with itself at two successive positions. This is achieved by calculating autocorrelation function. Autocorrelation is defined as the linear correlation between a time series at time $(t)$ and the same series at a later time $(t+\tau)[16]$.

$$
\begin{aligned}
& \text { Mathematically: } \\
& R_{x x}(t, t+\tau)=\lim _{n \rightarrow \infty}\left\{\frac{1}{n} \sum_{i=1}^{n}\left[Y_{t}(t) Y_{t}(t+\tau)\right]\right\} \quad n=0,1,2 \ldots .
\end{aligned}
$$

Where:

$$
R_{x x}(t, t+\tau) \text { is the autocorrelation coefficient }
$$$$
\tau \text { is the time interval in seconds. }
$$

Lag is the amount of offset between two successive series being compared. If each observation in a segment of time series is numbered from 1 to $i$, the autocorrelation has zero lag when element $1,2,3, \ldots i$ is compared to elements $1,2,3, \ldots i$ of another segment of the series. When the correlation coefficient of elements $1,2,3 \ldots i-1$ of one segment of the series are compared to elements $2,3,4, \ldots I$ of another segment of the same series, the autocorrelation has a lag of 1 . For a perfectly periodic data such as sine wave, the autocorrelation at zero lag equals 1. A typical autocorrelation will start from +1 at zero lag, decrease to a negative value less than or equal to -1 and then rise again. For a perfectly periodic data, the autocorrelation coefficient will vary from +1 to -1 .

\section{Materials and Methods}

\section{Experimental apparatus}

The experimental apparatus (Figure 1) consisted of four bioreactors, a feeding system, a temperature control system, a gas collection system, a data acquisition and control system and computer.

Bioreactors: Each bioreactor (Figure 2) was constructed of a cylindrical PVC vessel, (458 mm length, $300 \mathrm{~mm}$ diameter and a $10 \mathrm{~mm}$ wall thickness). It provided a liquid volume of $25 \mathrm{~L}$ and a gas head space of 7.4 L. The cover of the bioreactor was made of a transparent Plexiglas plate $(370 \mathrm{~mm}$ diameter and $10 \mathrm{~mm}$ thickness). It was secured to the bioreactor, through PVC lugs glued onto the top outer periphery of the vessel by means of six bolts. A Vaseline-coated rubber gasket was fitted between the cover and the vessel to provide a gas-tight seal. The

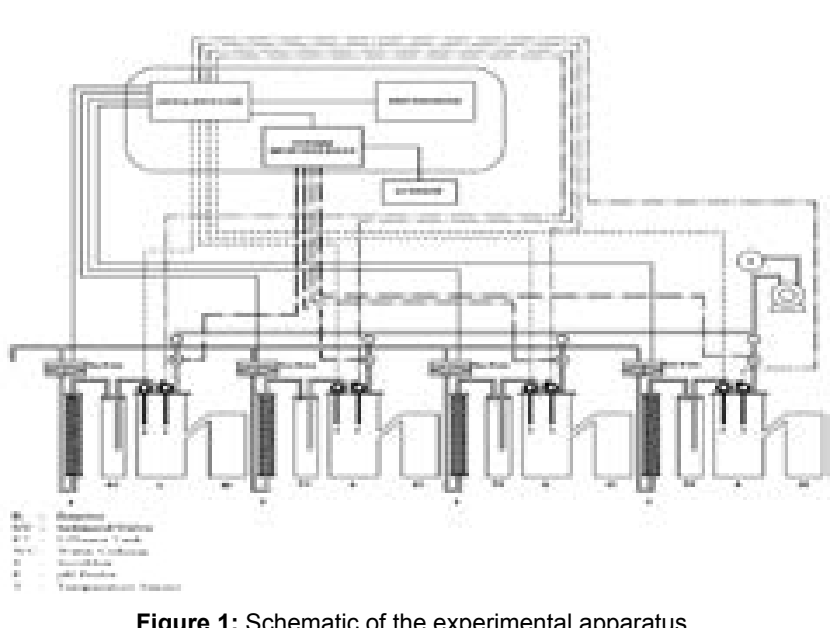

Figure 1: Schematic of the experimental apparatus. 


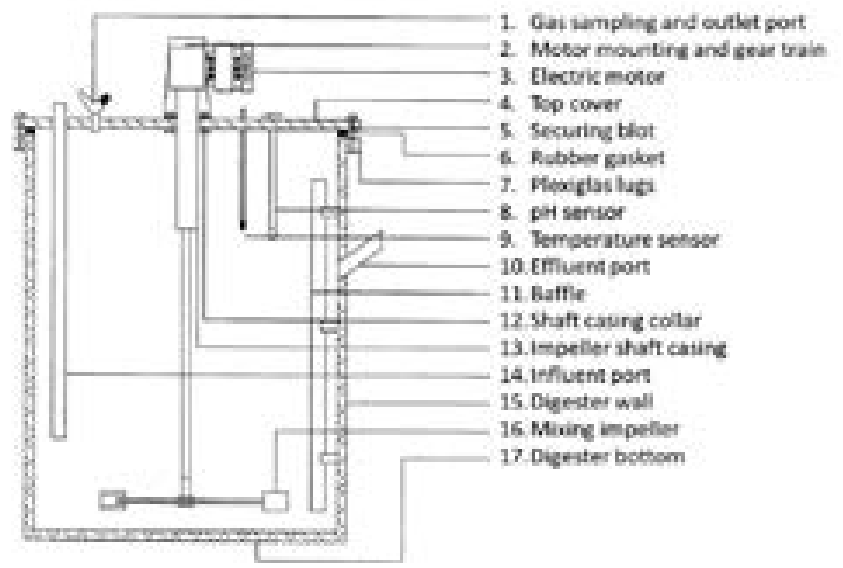

Figure 2: The continuous mix anaerobic bioreactor.

temperature and $\mathrm{pH}$ sensors were mounted on special holders threaded through the reactor cover and immersed to a depth of $100 \mathrm{~mm}$ below the liquid surface. The contents of the bioreactor were stirred by means of a flat-bladed impeller driven by a 1/12 HP electric motor (Model No6105061401, Franklin, Bluffton, Indiana, USA) at a speed of 125 rpm. The manure feed inlet consisted of a $25 \mathrm{~mm}$ diameter PVC tube inserted through the bioreactor cover to a depth of $246 . \mathrm{mm}$ below the liquid surface. The effluent port was located opposite to the feed inlet port at a distance of $300 \mathrm{~mm}$ above the bottom of the bioreactor.

Feeding system: The manure feeding system consisted of a manure storage tank, a feed pump, a set of tubing, a distribution manifold and a set of solenoid valves. A $60 \mathrm{~L}$ plastic container was used to store the manure and was fitted with a stirring paddle driven by a 1/12 HP electric motor (Model 55CP1OFG17AX, General Electric, Missisauga, Ontario, Canada) mounted on the tank cover. A feeding and ventilation ports were provided on the tank cover. The outlet port of the tank was located at the lower portion of the tank side. A peristaltic pump (Model 110-030, TAT Engineering Co., Logan, Ohio, USA) was used to feed the manure. At a rotational speed of $2 \mathrm{rpm}$ and an output of $0.138 \mathrm{~L}$ of manure per revolution, the pump delivered the manure at a capacity of $16.56 \mathrm{~L} / \mathrm{h}$ from the storage tank through the valve, tygon tubing, the distribution manifold and a set of automatically controlled solenoid valves to the individual reactors. A digital timer controlled and synchronized the operation of the feed tank stirrer (Model 5935932, Type NSI-10R93, Bodine Electric Co, North York, Ontario, Canada), the feed pump and the solenoid valves to ensure the delivery of a well mixed manure to the bioreactors at a predetermined sequence and loading rate. Eight feeding cycles were carried out daily at an interval of 3 hours.

Temperature control: The objective of the temperature control system was to maintain the profiles of the two temperature cycles (Figure 3 ) in the enclosed chamber in which the digesters were located. It consisted of an insulted chamber, a chiller, two heaters, two cross flow heat exchangers, two fans, temperature transducers and ducts for directing the circulation of air (Figure 4). The chamber was made of a $20 \mathrm{~mm}$ thick wooden box (2440 $\mathrm{mm}$ long, $710 \mathrm{~mm}$ wide and $525 \mathrm{~mm}$ deep) and divided into two compartments each was padded with $40 \mathrm{~mm}$ of Styrofoam insulation (R-value of $0.88 \mathrm{~m} 2 \mathrm{KIW}$ ). Each compartment was maintained at one of the two temperature profiles and contained two bioreactors. On the floor of each compartment was a U-shaped galvanized steel duct of 100 $\mathrm{mm}$ inside diameter. A fan, a heat exchanger and a heater were located

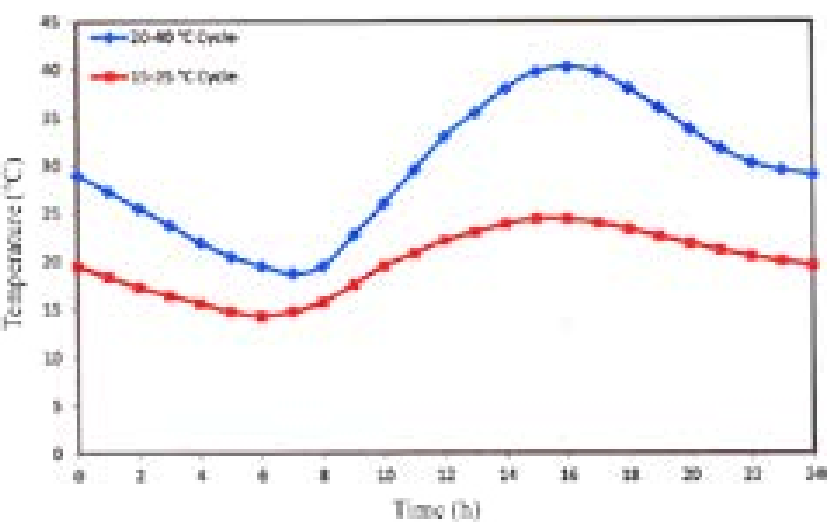

Figure 3: Diurnal air temperature profiles.

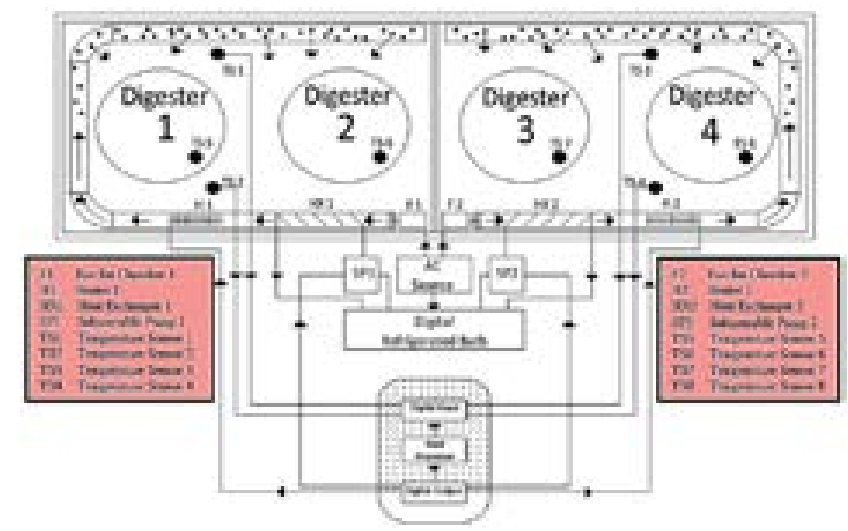

Figure 4: The temperature control system.

(in that order) inside one arm of each duct which circulated air in a closed loop. The fan drew air from the chamber into the duct and the air circulated over the heat exchanger and the heater and then left the duct through perforations on the other two sections of the U-shaped duct to bathe the bioreactor. The air was circulated using a thermally protected electric fan (Model 4C02A, Dayton Electric Manufacturing. Co., Nues, Illinois, USA). The capacities of the heaters were 750 and $500 \mathrm{~W}$ for the compartments operated at the higher and lower cyclic temperature ranges, respectively. A digital rapid cool refrigerated bath (Series 900, Polyscieñce, Nues, Illinois, USA) with an operating temperature range of -35 to $150{ }^{\circ} \mathrm{C}$ ) and an accuracy of $\pm 0.02^{\circ} \mathrm{C}$ was use. The chiller had a maximum cooling capacity of $425 \mathrm{~W}$ at $20^{\circ} \mathrm{C}$ ( or $225 \mathrm{~W}$ at $-10^{\circ} \mathrm{C}$ ), a bath capacity of $13 \mathrm{~L}$ and can deliver a maximum flow of $15 \mathrm{~L} / \mathrm{min}$ at zero head. Two submersible pumps (Model 1 -MA, Little Giant, Bluffton, Indiana, USA), each delivered chilled water to one of the two heat exchangers, were immersed inside the chiller bath. With a power consumption of $3.73 \mathrm{~W}$, each pump had a rated capacity of $10.72 \mathrm{~L} / \mathrm{min}$ at $0.3 \mathrm{~m}$ and a maximum pumping height of $1.85 \mathrm{~m}$. A Styrofoam cover of the same thickness as the wall insulation was provided for each of the chamber compartments in such a way that visual examination of the content of the reactors was possible without removing the covers. Four temperature sensors (TS 1 \& TS2 and TS3 \& TS4) were mounted on the chamber covers (two for each compartment). During operation, the temperature transducers continuously sampled the air temperature in each of the chamber compartments and transmitted the signals 
through the digital input node of the data acquisition system to the host processor. Every 30 seconds, the host processor computed the average temperature of each compartment and compared these with set point values. Depending on the error signal, the host processor generated a correction signal which either turned the heaters and the chilled water submersible pumps on and off (or vice versa), respectively.

Gas collection: Gas collection was effected through a Y-shaped nipple fitted on the cover. One end of the nipple carried a rubber septum through which gas samples were drawn with a syringe. The other arm of the nipples was fitted with flexible tubing which conveyed the evolved gases through a water column, gas scrubber and gas meter to the gas collection and storage system. The water column was used to provide back pressure in the reactor to maintain a constant liquid level. The scrubber was made of a gas-tight Plexiglas column $(80 \mathrm{~mm}$ diameter and $450 \mathrm{~mm}$ long) filled with steel wool to strip the biogas of hydrogen sulfide. The gas meter was a tipping balance meter which indicated when $50 \pm 2 \mathrm{~mL}$ of gas had been collected. The collected gas was subsequently pumped into a gas cylinder by means of a compressor.

Manure collection, preparation and storage: Dairy manure was collected from a commercial dairy farm located in Stewiacke, Nova Scotia, Canada, The manure was scrapped off the floor of the dairy barn and screened using a modified fish de-boner (Model SDX16, Bibun, Japan). During the sieving process, tap water was added to dilute the manure to $6.5 \%$ solid content. The manure was placed in buckets of $30 \mathrm{~L}$ and the buckets were sealed and transported to a commercial freezing plant (Associated Freezers, Dartmouth, Nova Scotia, Canada) where they were stored at $-25^{\circ} \mathrm{C}$ until needed. When needed, buckets of manure were removed from the freezer and kept at room temperature in the Waste Management Laboratory to thaw for 48 hours and the manure was then loaded into the feeding tank. Some characteristics of raw manure are shown in Table 1.

\section{Start-up procedure}

The bioreactors were started by adding $18.0 \mathrm{~L}$ (to each reactor) of actively digesting sewage sludge obtained from Mill Cove Municipal Wastewater Treatment Plant (Bedford, Nova Scotia, Canada). This

\begin{tabular}{|c|c|}
\hline Parameter & Mean Value* \\
\hline 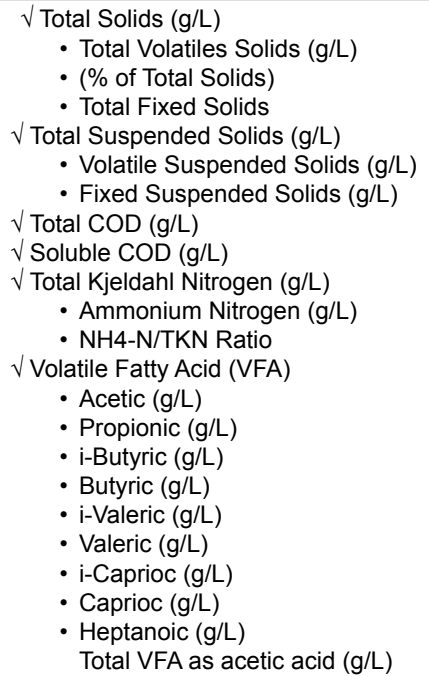 & $\begin{array}{l}64.25 \\
50.26 \\
78.23 \\
13.99 \\
42.25 \\
31.00 \\
11.25 \\
98.80 \\
27.90 \\
3.80 \\
2.45 \\
0.64 \\
\\
1.55 \\
0.28 \\
0.04 \\
0.06 \\
0.04 \\
0.02 \\
0.01 \\
0.01 \\
0.04 \\
1.91\end{array}$ \\
\hline
\end{tabular}

*Each value represents the average of 5 samples

Table 1: Characteristics of raw manure. was followed by the addition of $7.0 \mathrm{~L}$ of screened dairy manure. The temperature control and the data acquisition systems were activated and the digesters were operated in batch mode for 48 hours. The feeding system was used to feed the reactors. Reactors R1 and R2, were operated at the diurnal temperature cycle of $20-40^{\circ} \mathrm{C}$ and received feed at rates of 0.33 and $0.42 \mathrm{~L} / \mathrm{d}$, respectively. Reactors $\mathrm{R} 3$ and $\mathrm{R} 1$ were operated at the diurnal temperature cycle of $15-25^{\circ} \mathrm{C}$ and received feed at rates of 0.33 and $0.42 \mathrm{~L} / \mathrm{d}$, respectively. Feeding rates were equivalent to hydraulic retention times (HRTs) of 75 days for the feeding rate of $0.33 \mathrm{~L} / \mathrm{d}$ and 60 days for the feeding rate of $0.42 \mathrm{~L} / \mathrm{d}$. The feeding rates were then adjusted to $0.5 \mathrm{~L} / \mathrm{d}$ for reactors $\mathrm{R} 1$ and $\mathrm{R} 3$ and $0.63 \mathrm{~L} / \mathrm{d}$ for R2 and $\mathrm{R} 1$ and were held constant for 72 hours. These rates corresponded to HRTs of 50 and 40 days, respectively. These rates were maintained for another 48 hours.

\section{Operating procedure}

After 7 days from start-up, R1 and R3 were operated at an HRT of 25 days while R2 and R4 were operated at an HRT of 20 days. The startup period was concluded after a period of 32 days. Following the initial start-up period, monitoring of the biogas production was started on day 33 (from the start). Steady state was construed to have been achieved when a uniform gas production and/or uniform effluent quality were achieved. Once the steady-state was achieved at a given retention time, the system parameters were measured monitored for a period of at least five days. The feeding rates of the reactors were adjusted for the next set of retention times ( 15 days for reactors $\mathrm{R} 1$ and $\mathrm{R} 3$ and 10 days for reactors R2 and R4). When the steady state was attained, sampling monitoring was continued for five days.

Analyses: The liquid samples were analyzed for total solids (TS), total volatile solids (TVS), total fixed solids (TFS) and volatile fatty acids (VFA) whereas the biogas samples were analyzed for gas composition.

Solids: The total solids analyses were performed according to procedures described in the Standard Method for the Examination of Water and Wastewater [17].

Volatile fatty acids: The individual volatile acids (C2-C7) contained in a sample were determined using a Hewlett-Packard gas chromatograph (Model 5890 series II, Mississauga, Ontario, Canada) equipped with an HP 76734A automatic injector. Extraction of the VFA was carried out by acidifying $3.0 \mathrm{~mL}$ of each of the manure samples using $0.1 \mathrm{~mL} 30 \%$ sulphuric acid. The acidified samples were well mixed and centrifùged at $7000 \mathrm{rpm}$ for 20 minutes. $2.0 \mathrm{~mL}$ of the supernatants were decanted and an equal amount of diethyl ether was added. The mixtures were well shaken and then centrifuged at 5000 $\mathrm{rpm}$ for 5 minutes to break down the emulsion layer. The upper layer which consisted of di-ethyl ether was removed for analysis. Volatile acids were, also, extracted from a volatile acid standard mixture (No46975, SupelCo, Oakville, Ontario, Canada) using di-ethyl ether. The chromatograph was calibrated by injecting $1.0 \mathrm{~mL}$ of the extracted standard VFA mixture into the $25 \mathrm{~mm}$ x $0.2 \mathrm{~mm}$ capillary column of the liquid chromatography whose film thickness is $0.33 \mathrm{~mm} .1 .0 \mathrm{~mL}$ of the extracted samples were injected into the column. A split ratio of 1:5 was applied. The column temperature was first maintained at $60^{\circ} \mathrm{C}$ for 3 minutes and then increased at a rate of $10^{\circ} \mathrm{C}$ per minute until a temperature of $150{ }^{\circ} \mathrm{C}$ was attained. The column temperature was maintained at $150^{\circ} \mathrm{C}$ for 2 minutes. The injector was set to $180^{\circ} \mathrm{C}$ while the flame ionization detector was set at $250^{\circ} \mathrm{C}$. The carrier gas was 
helium at a flow rate of $1.2 \mathrm{~mL} / \mathrm{mm}$.

Biogas composition: The composition of biogas was determined using a gas chromatograph (Model HP 5980A, Hewlett Packard, Mississauga, Ontario, Canada). Samples of $0.1 \mathrm{~mL}$ were taken from the gas collected in the sampling tube using a gas tight locked syringe. The samples were injected into $152.4 \mathrm{~mm} \times 3.2 \mathrm{~mm}$ (6 in $\times 1 / 8$ in) OD porapak Q stainless steel column of the gas chromatograph which is connected in a series bypass arrangement with a $152.4 \mathrm{~mm} \times 3.2 \mathrm{~mm}$ ( 6 in X 1/8 in) OD molecular sieve 5A 60180 stainless steel column. The switch valve of the gas chromatograph was adjusted to permit the molecular sieve column to store nitrogen, methane and carbon monoxide until the elution of the $\mathrm{CO} 2, \mathrm{C} 2 \mathrm{H} 2$ and $\mathrm{C} 6 \mathrm{H} 6$ through the porapak Q stainless steel column. The column was maintained at $45^{\circ} \mathrm{C}$ with helium as the carrier gas at $30 \mathrm{ml} / \mathrm{min}$. The injector was set at $150^{\circ} \mathrm{C}$ while the thermal conductivity detector was set at $250^{\circ} \mathrm{C}$.

\section{Results and Discussion}

\section{Temperature}

Typical variations of reactor temperatures with those of the chambers for the $20-40^{\circ} \mathrm{C}$ and $15-25^{\circ} \mathrm{C}$ diurnal temperature cycles are shown in Figure 5. A summary of the reactor temperature profiles at the various operating conditions is presented in Table 2. The mean minimum and maximum temperatures for the reactors operating under the $20-40^{\circ} \mathrm{C}$ cycle were $25.5^{\circ} \mathrm{C}$ and $33.8^{\circ} \mathrm{C}$, respectively. The mean amplitude for the $20-40^{\circ} \mathrm{C}$ cycle was $\pm 8.3^{\circ} \mathrm{C}$. The mean minimum and maximum temperatures for the $15-25^{\circ} \mathrm{C}$ cycle were $18.6^{\circ} \mathrm{C}$ and $22.8^{\circ} \mathrm{C}$, respectively. The mean amplitude for the $15-25^{\circ} \mathrm{C}$ cycle was $\pm 4.2^{\circ} \mathrm{C}$.

Relative to air temperature, there was a lag in the reactor temperature at both the maximum and minimum temperatures of both temperature cycles. The mean lag at the maximum and minimum temperatures for the $15-25^{\circ} \mathrm{C}$ cycle and the $20-40^{\circ} \mathrm{C}$ cycle were $3.37 \mathrm{~h}$ and $3.95 \mathrm{~h}$ and 3.38 $\mathrm{h}$ and $4.35 \mathrm{~h}$, respectively. This was due to the significant differences between the density of air in the chamber and the liquid medium in the reactor and the thermal properties of the reactors' walls which affected the rate of heat transfer to and from the reactors.

\section{Solids}

The average values of total, fixed and volatile solids concentrations of the effluent samples collected during the steady state and their reductions are shown in Table 3 . The diurnal variations in the total

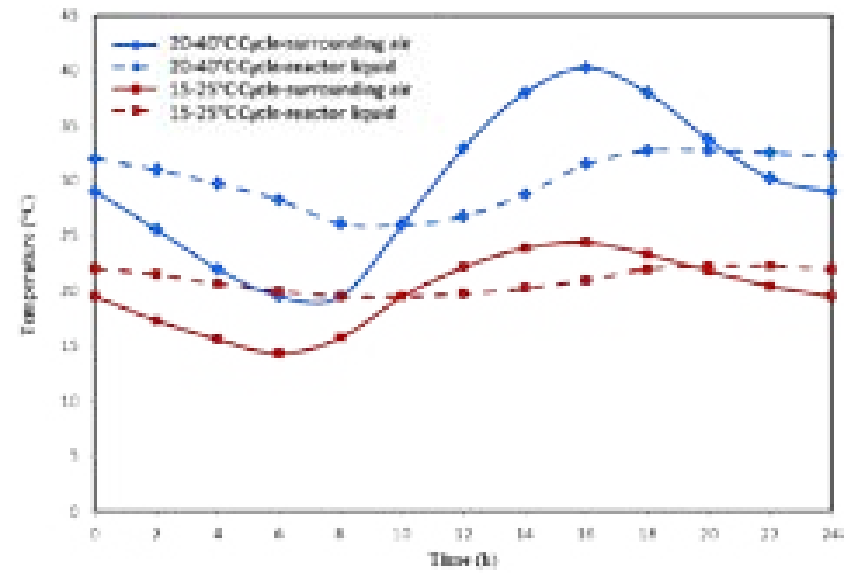

Figure 5: Diurnal variations in bioreactor and ambient temperatures. solids of the effluent collected over a $24 \mathrm{~h}$ period during the steady state are shown in Figure 6.

\section{Total solids}

Diurnally cyclic variations in the effluent total solids were observed under the $20-40^{\circ} \mathrm{C}$ cycle. However, the diurnally cyclic variations in total solids were not distinct at the 15 and $10 \mathrm{~d}$ HRTs under the $15-25^{\circ} \mathrm{C}$ cycle. Similar diurnally cyclic variations were observed for the effluent total volatile solids and total fixed solids.

For the $20-40^{\circ} \mathrm{C}$ cycle, the TS reductions ranged from 30.3 to $36.8 \%$ ( 19.45 to $23.65 \mathrm{~g} / \mathrm{L}$ ), the TVS reductions ranged from 34.9 to $40.3 \%$ ( 17.56 to $20.26 \mathrm{~g} / \mathrm{L}$ ) while the TFS reductions ranged from 13.5 to $24.2 \%(1.89$ to $3.39 \mathrm{~g} / \mathrm{L})$, depending on the hydraulic retention time. For the $15-25^{\circ} \mathrm{C}$ cycle, the TS reductions ranged from 24.4 to $38.3 \%$ ( 15.65 to $24.55 \mathrm{~g} / \mathrm{L}$ ), the TVS reductions ranged from 25.2 to $39.7 \%$ (12.66 to $19.96 \mathrm{~g} / \mathrm{L}$ ) while the TFS reductions ranged from 21.4 to $32.8 \%(2.99$ to $4.59 \mathrm{~g} / \mathrm{L})$, depending on the hydraulic retention time. Higher TS reductions were achieved with the high diurnal temperature cycle $\left(20-40^{\circ} \mathrm{C}\right)$ than those with the lower diurnal temperature cycle $\left(15-25^{\circ} \mathrm{C}\right)$ at all HRTs.

Wilkie et al. [18] obtained the highest TS reduction of $46.7 \%$ during the treatment of dairy manure at a low temperature range of 11.7-32. $4^{\circ} \mathrm{C}$. Elango et al. [19] achieved a TS reduction of $87.6 \%$ during the treatment of solid wastes over the temperature range of 26 to $36^{\circ} \mathrm{C}$. The TS reduction achieved in the present study (25.2-39.7) is within the values reported in the literature. The hydraulic retention time (HRT) had a significant effect on the TS reduction in the present study. Generally, the shorter the HRT, the lower the solids reductions. Ribas and Barana [20] reported that a decrease in the HRT from 16.6 to $9.7 \mathrm{~d}$ increased the TS of anaerobically treated wastewater from 2.3 to $4.8 \%$. Umana et al. [21] reported an increase in the TS removal efficiency from 14.6 to $68.8 \%$ when the HRT was increased from 1 to $5.5 \mathrm{~d}$ during the treatment of dairy manure. Rico et al. [22] noted that the concentration of TS increased from 39.2 to $45.3 \mathrm{~g} / \mathrm{L}$ as the HRT was decreased from 20 to $10 \mathrm{~d}$ during the treatment of dairy manure.

\section{Volatile solids}

The absolute values of TVS reductions (g/L) were generally lower than those of the TS. This may be explained by the fact that volatile solids are converted to microbial biomass, volatile fatty acids (VFAs)

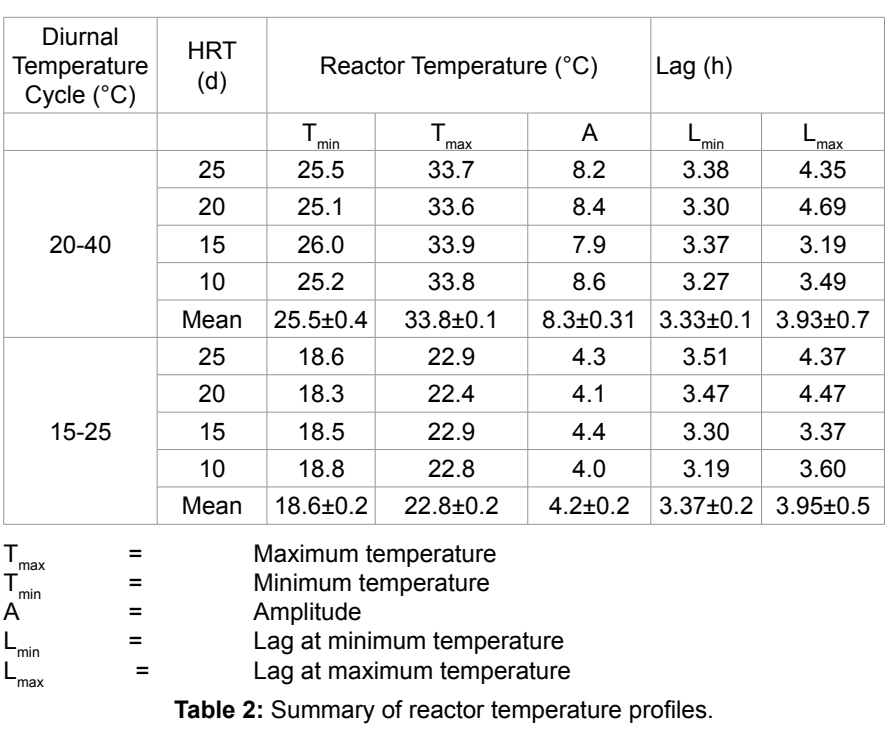


Page 6 of 12

\begin{tabular}{|c|c|c|c|c|c|c|c|c|c|c|}
\hline \multirow{3}{*}{$\begin{array}{l}\text { Diurnal Temperature Cycle } \\
\qquad\left({ }^{\circ} \mathrm{C}\right)\end{array}$} & \multirow{3}{*}{ HRT (d) } & \multicolumn{3}{|c|}{ TS } & \multicolumn{3}{|c|}{ TFS } & \multicolumn{3}{|c|}{ TVS } \\
\hline & & \multirow{2}{*}{$\begin{array}{l}\text { Mean } \\
(g / L)\end{array}$} & \multicolumn{2}{|c|}{ Reduction } & \multirow{2}{*}{$\begin{array}{c}\text { Mean } \\
(g / L)\end{array}$} & \multicolumn{2}{|c|}{ Reduction } & \multirow{2}{*}{$\begin{array}{l}\text { Mean } \\
(\mathrm{g} / \mathrm{L})\end{array}$} & \multicolumn{2}{|c|}{ Reduction } \\
\hline & & & (g/L) & $(\%)$ & & (g/L) & $(\%)$ & & (g/L) & (\%) \\
\hline \multirow[t]{4}{*}{$20-40$} & 25 & 40.60 & 23.65 & 36.8 & 10.60 & 3.39 & 24.2 & 30.0 & 20.26 & 40.3 \\
\hline & 20 & 41.30 & 22.95 & 35.7 & 10.90 & 3.09 & 26.4 & 30.4 & 19.86 & 39.5 \\
\hline & 15 & 44.10 & 20.45 & 31.4 & 11.80 & 2.19 & 15.7 & 32.3 & 17.96 & 35.7 \\
\hline & 10 & 44.80 & 19.45 & 30.3 & 12.10 & 1.89 & 13.5 & 32.7 & 17.56 & 34.9 \\
\hline \multirow[t]{4}{*}{$15-25$} & 25 & 39.70 & 24.55 & 38.2 & 9.40 & 4.59 & 32.8 & 30.3 & 19.96 & 39.7 \\
\hline & 20 & 44.90 & 19.35 & 30.1 & 10.20 & 3.79 & 27.1 & 34.7 & 15.56 & 30.9 \\
\hline & 15 & 47.30 & 16.95 & 26.4 & 10.60 & 3.39 & 25.7 & 36.7 & 13.56 & 26.9 \\
\hline & 10 & 48.60 & 15.65 & 24.4 & 11.00 & 2.99 & 21.4 & 37.4 & 12.66 & 25.2 \\
\hline
\end{tabular}

TS $\quad=\quad$ Total solids

TFS $\quad=\quad$ Total fixed solids

TVS $\quad=\quad$ Total volatile solids

Initial TS $=64.25 \mathrm{~g} / \mathrm{L}$

Initial VS $=\quad 50.26 \mathrm{~g} / \mathrm{L}$

Initial FS $=\quad 13.99 \mathrm{~g} / \mathrm{L}$

Table 3: Total solids.
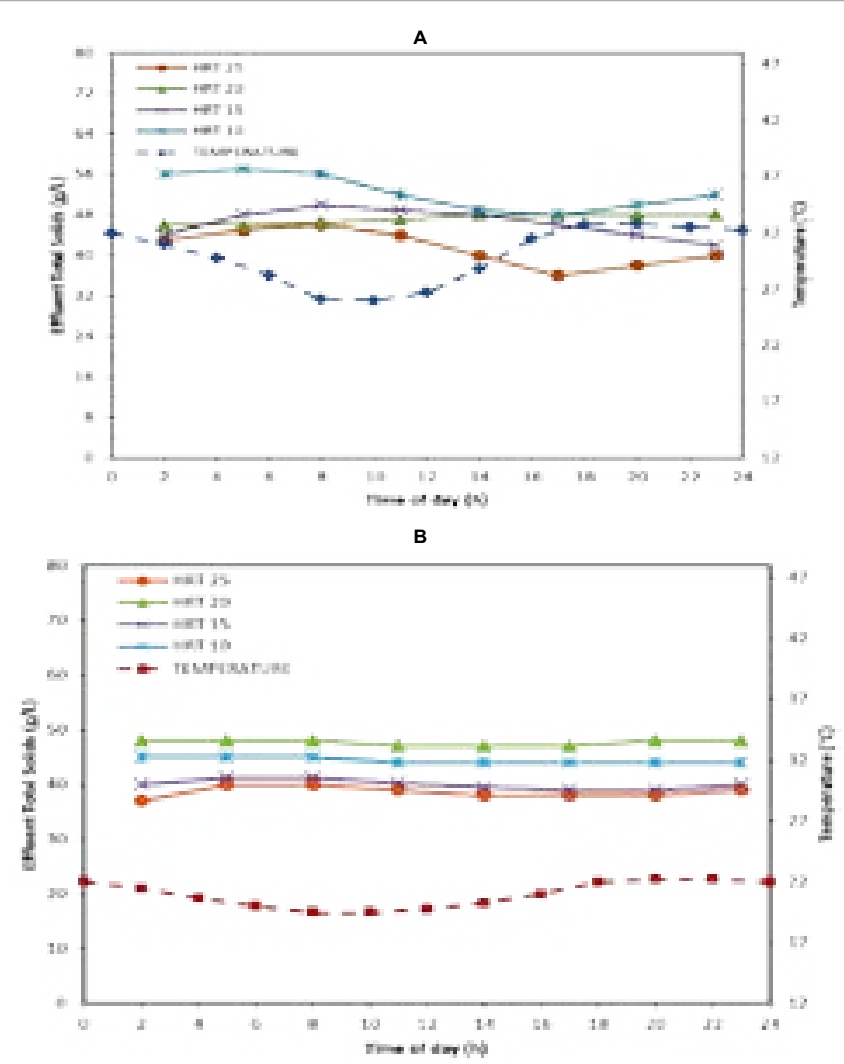

Figure 6: Diurnal variation in total solids. (a) $20-40^{\circ} \mathrm{C}$ Diurnal Temperature Cycle. (b) $15-25^{\circ} \mathrm{C}$ Diurnal Temperature Cycle.

and biogas. While microbial biomass contributes to the total solids content of the effluent, the VFAs are evaporated at $105^{\circ} \mathrm{C}$ and therefore, are not detected in TS measurements [23].

The HRT had a significant effect on the effluent TVS. Generally, the shorter the HRT the lower the TVS reduction. De la Rubia et al. [24] reported an increase in the TVS reduction (from 53 to $73 \%$ ) as the HRT increased from 27 to $75 \mathrm{~d}$. Ribas and Barana [20] reported an increase in the TVS from 1.6 to $4.3 \%$ in a wastewater treatment system as the HRT was decreased from 16.6 to $9.7 \mathrm{~d}$. Umana et al. [21] reported an increase in the TVS reduction (from 26.3 to $78.8 \%$ ) during the treatment of dairy manure as the HRT was increased from 1 to 5.5 d. Rico et al. [22] noted that the concentration of TVS increased from 23.7 to $27.8 \mathrm{~g} / \mathrm{L}$ during anaerobic treatment of dairy manure as the HRT decreased from 20 to $10 \mathrm{~d}$. The reduction in the TVS obtained in this study (25.2-39.7 \%) was within the range reported in the literature.

The diurnal cycling temperature also affected the TVS reductions, the higher the temperature the higher the TVS reduction. Wilkie et al. [18] achieved the highest TVS reduction of $60.4 \%$ at a temperature of $32.4^{\circ} \mathrm{C}$ during the treatment of dairy manure wastewaters. Elango et al. [19] reported $88.1 \%$ reduction in TVS over the temperature range of 26 to $36^{\circ} \mathrm{C}$. Trazcinski and Stuckey [25] reported TVS reductions in the range of $40-75 \%$ at the temperatures of $21-35^{\circ} \mathrm{C}$ during anaerobic digestion of solid waste. The TVS reductions achieved in this study (25.2-39.7\%) are within the range reported in the literature.

\section{Fixed solids}

Fixed solids represent the inorganic components of the waste and it consists of potassium, sodium, calcium, magnesium, iron, copper and other minerals [23]. Unlike carbon and nitrogen, little or no significant losses in these inorganic compounds are generally expected to occur since they do not play a very significant role in the anaerobic digestion process. In this system, a fixed solid recovery ranging from 64.3 to 112.0 $\%$ was recorded.

Converse et al. [26] reported a fixed solid recovery ranging from 90 to $104 \%$. In this study, the losses in fixed solids may have been due to inadequate mixing of the bioreactor contents which may have resulted in the settling out of the inorganic mineral resulting in the lower concentration of these compounds in the effluent. They may, also, have been due to the fact that changes in the nature of these inorganic compounds may have occurred at the higher temperature $\left(550^{\circ} \mathrm{C}\right)$ used in the determination of total ash content.

\section{Volatile fatty acids}

The concentrations of volatile fatty acids (VFAs) in the effluent samples taken during the steady state conditions are shown in Table 4. The VFAs included: acetic, propionic, isobutyric, iso-valeric, valeric, iso-caprioc and heptanoic acids.

The VFAs concentration in the effluent ranged from 45 to 1200 $\mathrm{mg} / \mathrm{L}$, depending on the operating conditions. The effluent VFAs concentration generally increased with decreases in the HRT and higher VFAs concentrations were recorded at the lower temperature cycle. At 


\begin{tabular}{|c|c|c|c|c|c|c|c|c|c|c|c|}
\hline \multirow{2}{*}{$\begin{array}{c}\text { Temp } \\
\left({ }^{\circ} \mathrm{C}\right)\end{array}$} & \multirow{2}{*}{$\begin{array}{c}\text { HRT } \\
\text { (d) }\end{array}$} & \multicolumn{10}{|c|}{ Volatile Acid Concentration (mg/L) } \\
\hline & & Acetic Acid & $\begin{array}{l}\text { Propionic } \\
\text { Acid }\end{array}$ & $\begin{array}{c}\text { i-Butyric } \\
\text { Acid }\end{array}$ & $\begin{array}{c}\text { n-Butyric } \\
\text { Acid }\end{array}$ & $\begin{array}{l}\text { i-Valeric } \\
\text { Acid }\end{array}$ & $\begin{array}{c}\text { n-Valeric } \\
\text { Acid }\end{array}$ & $\begin{array}{c}\text { i-Caproic } \\
\text { Acid }\end{array}$ & $\begin{array}{c}\text { n-Caproic } \\
\text { Acid }\end{array}$ & $\begin{array}{l}\text { Heptanoic } \\
\text { Acid }\end{array}$ & $\begin{array}{c}\text { Total as } \\
\text { Acetic Acid }\end{array}$ \\
\hline \multirow{4}{*}{$20-40$} & 25 & 5.5 & 26.6 & 15.6 & 8.4 & 9.8 & $<0.01$ & 11.7 & 3.9 & 5.7 & 60.0 \\
\hline & 20 & 44.0 & $<0.01$ & $<0.01$ & $<0.01$ & $<0.01$ & $<0.01$ & $<0.01$ & $<0.01$ & $<0.01$ & 44.7 \\
\hline & 15 & 3.0 & 26.0 & 10.7 & 11.3 & 9.7 & 1.3 & 3.3 & 2.4 & 2.5 & 50.0 \\
\hline & 10 & 53.8 & 56.9 & 35.7 & 8.2 & 11.5 & 5. & 9.0 & 4.7 & 16.9 & 154.8 \\
\hline \multirow{4}{*}{$15-25$} & 25 & 54.1 & 73.6 & 13.7 & 18.3 & 3.9 & $<0.01$ & 2.2 & 5.4 & 20.0 & 151.0 \\
\hline & 20 & 70.8 & 102.1 & 19.1 & 26.0 & 19.8 & 4.7 & 6.1 & 6.1 & 58.4 & 231.8 \\
\hline & 15 & 207.4 & 92.0 & 18.5 & 27.6 & 19.7 & 4.1 & 6.6 & 4.3 & 59.4 & 362.5 \\
\hline & 10 & 645.0 & 431.4 & 139.7 & 38.6 & 36.0 & 25.0 & 22.7 & 17.8 & 30.1 & 1187.0 \\
\hline \multicolumn{2}{|c|}{ Raw Manure } & 1548.4 & 283.5 & 44.5 & 60.5 & 40.2 & 21.0 & 7.0 & 11.3 & 37.1 & 1913.0 \\
\hline
\end{tabular}

the $20-40^{\circ} \mathrm{C}$ diurnal temperature cycle, the VFAs (measured as acetic acid) first decreased from 60 to $44.7 \mathrm{mg} / \mathrm{L}$ as the HRT was reduced from 25 to $20 \mathrm{~d}$. Further reductions in the HRT resulted in increasingly higher concentrations of VFAs, up to $154.8 \mathrm{mg} / \mathrm{L}$ was recorded at the 10 day HRT. Among the individual volatile acids, propionic acid had the highest concentration at all but $20 \mathrm{~d}$ HRT. At the $20 \mathrm{~d}$ HRT, only acetic acid was detected in measurable levels. At the $15-25^{\circ} \mathrm{C}$ diurnal temperature cycle, the total volatile acids concentration increased from $151.0 \mathrm{mg} / \mathrm{L}$ at the $25 \mathrm{~d}$ HRT to $1187.0 \mathrm{mg} / \mathrm{L}$ at the $10 \mathrm{~d}$ HRT. Propionic acid concentration was higher than that of the rest at the 25 and $20 \mathrm{~d}$ HRTs while acetic acid concentration was the highest at the 15 and 10 d HRTs.

The HRT has a significant influence on the production of VFAs, the shorter the HRT the higher the VFAs concentration. Colmenarejo et al. [27] reported that the highest VFAs production was achieved when the HRT was decreased from 5.2 to $1.7 \mathrm{~h}$. El-Mashad et al. [28] reported that the VFA concentration increased when the HRT was decreased from 24 to $3 \mathrm{~h}$ during the treatment of domestic wastewater. Elefsiniotis and Oldham [29] reported an increase in VFA production when the HRT was increased from 6 to $12 \mathrm{~h}$ which then decreased with further increase in the HRT to $15 \mathrm{~h}$. Maharaj and Elefsiniotis [30] noted highest VFA concentration at an HRT of $30 \mathrm{~h}$ as appose to 48 and $60 \mathrm{~h}$ while anaerobically treating wastewaters. De la Rubia et al. [24] found that the VFA production increased from 5532 to $6432 \mathrm{mg} / \mathrm{L}$ as the HRT decreased from 75 to 20 days.

The results also showed the importance of temperature on the production of VFAs. Higher VFA production was observed with lower diurnal cyclic temperature. Maharaj and Elefsiniotis [30] noted increased VFA concentrations as the temperature was increased from 8 to $25^{\circ} \mathrm{C}$, which then decreased upon further increase in temperature (from 25 to $35^{\circ} \mathrm{C}$ ). Choorit and Wisarnwan [31] noted that the VFA concentration slightly increased from 160.71 to $166.64 \mathrm{mg} / \mathrm{L}$ as the temperature decreased from 43 to $37^{\circ} \mathrm{C}$ and from 245.07 to 338.71 $\mathrm{mg} / \mathrm{L}$ as the temperature decreased from 55 to $49^{\circ} \mathrm{C}$. De la Rubia et al. [24] observed an increase in VFA production from 830 to 5688 $\mathrm{mg} / \mathrm{L}$ during digestion anaerobic municipal sludge as the temperature increased from 35 to $55^{\circ} \mathrm{C}$.

However, values of effluent VFAs concentrations reported in the literature vary depending on the type of waste. Converse et al. [27] reported effluent VFAs concentrations of $423-1113 \mathrm{mg} / \mathrm{L}$ (as acetic acid) using CSTR operated on dairy manure of 12.8-13.4\% TS content and a temperature of $35^{\circ} \mathrm{C}$. Jeyanayagam and Collins [32] reported effluent VFAs concentrations of 754-1515 mg/L using laboratory digesters operated on dairy manure of 4.0-6.5 \% TS content at hydraulic retention times of $15-20 \mathrm{~d}$ and a temperature of $35^{\circ} \mathrm{C}$. Lo and Liao [33] reported a VFAs concentration of $584 \mathrm{mg} / \mathrm{L}$ using a fixed film reactor operated on a screened dairy manure of $3.7 \%$ TS content at an HRT of $20 \mathrm{~d}$ and a temperature of $12^{\circ} \mathrm{C}$. Peck et al. [34] reported effluent VFAs concentrations of $64-98 \mathrm{mg} / \mathrm{L}$ using manure of $3458-4109 \mathrm{mg} / \mathrm{L}$ TS at $10-25 \mathrm{~d}$ HRTs and a temperature of $35^{\circ} \mathrm{C}$. The VFA concentrations observed in this study are within the range of values reported in the literature.

Organic wastes are first converted to long chain fatty acids in the acidogenic stage of anaerobic digestion processes. Volatile acids are further converted to acetic acid which together with hydrogen and formate serve as substrates for methane bacteria. Different species of anaerobic bacteria are involved in the conversion of specific long chain fatty acids to acetic acid. The increased proportion of propionic acid relative to acetic acid indicated that the different species of anaerobic bacteria did not respond in a similar manner to the effect of diurnally cyclic temperature. The fact that individual VFAs are removed at different rates under adverse conditions such as a drop in temperature has been observed by other researchers [34] A lower methane yield was recorded under the conditions in which the propionic acid concentration was high indicating that propionic acid was not available for conversion to methane.

\section{Biogas}

Figure 7 shows the daily biogas production under various operating conditions. The diurnal variations in the mean rate of biogas production for the $25 \mathrm{~h} \mathrm{HRT}$ are shown in Figure 8. A summary of the average composition of the biogas collected under the various treatment combinations is shown in Table 5. Typical results of the autocorrelation and Fourier analysis are shown in Figures 9-12.

\section{Biogas production}

There appears to be a definite relationship between the bioreactor temperature and the rate of biogas production. Biogas production followed a diurnally cyclic pattern similar to that of the bioreactor temperature under most operating conditions. The highest reactor temperature and the maximum rate of biogas production occurred at the 18 hour while the lowest reactor temperature and the minimum biogas production rate occurred at the 9 hour. This trend was observed at all HRTs with $20-40^{\circ} \mathrm{C}$ cycle and at the $20 \mathrm{~d}$ HRT with $15-25^{\circ} \mathrm{C}$ cycle. The daily amplitude of the gas production cycle was higher under the $20-40^{\circ} \mathrm{C}$ cycle than that observed under the $15-25^{\circ} \mathrm{C}$ cycle. Smaller amplitudes in the gas production cycle were recorded in the lower temperature cycle at all HRTs because of the smaller diurnal amplitude of the reactor temperature. With digesters operated under stressful 

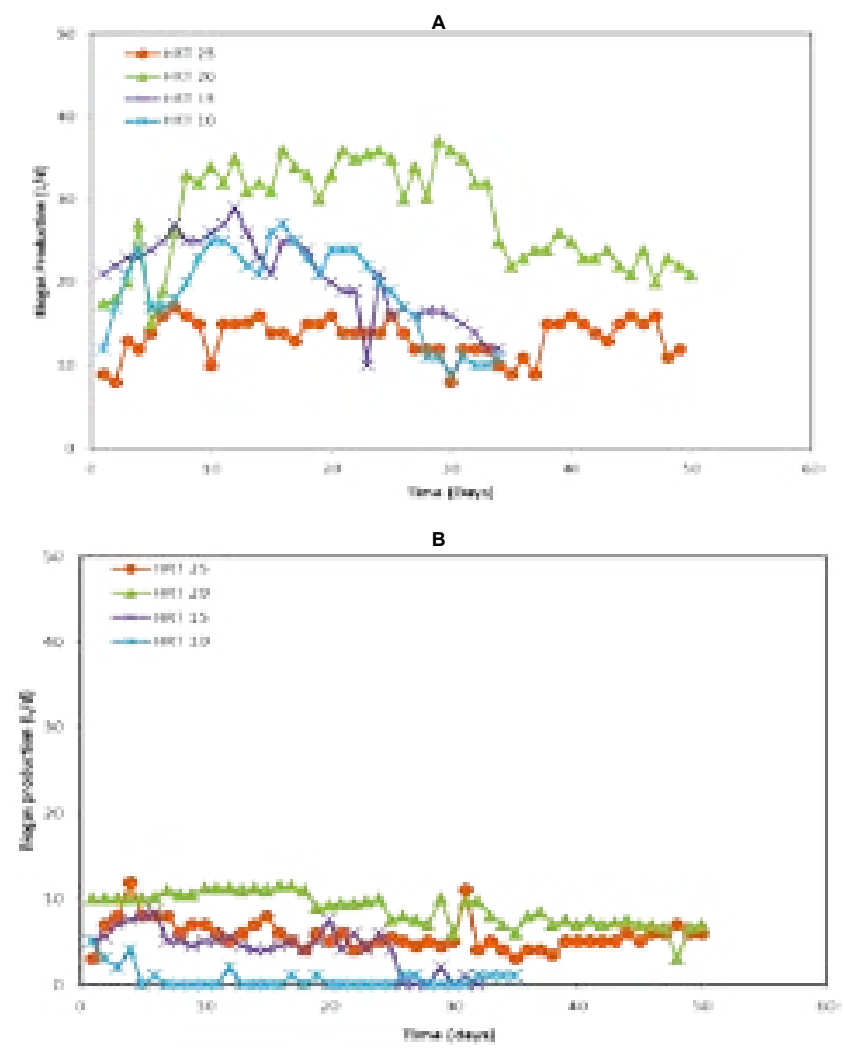

Figure 7: Daily biogas production. (a) $20-40^{\circ} \mathrm{C}$ Diurnal Temperature Cycle. (b) $15-25^{\circ} \mathrm{C}$ Diurnal Temperature Cycle

conditions such as a combination of low temperature $\left(15-25^{\circ} \mathrm{C}\right)$ and high loading rate (short HRT), the recorded diurnal variations in the rate of biogas production were either less pronounced or non-existent. The direct relationship between the rate of biogas production and the reactor temperature is supported by the known fact that microbial activity increases with increases in the reaction temperature.

Under the operating temperature cycle of $15-25^{\circ} \mathrm{C}$, a steady gas production was achieved at the $25 \mathrm{~d}$ HRT only after a few days whereas at the $20 \mathrm{~d}$ HRT, a steady, but not rapid, decline in biogas production was observed after the $15^{\text {th }}$ day, following the initial rise in biogas production. At the $15 \mathrm{~d}$ HRT, the gas production declined unsteadily after the first 8 days until it completely stopped at the $28^{\text {th }}$ day. At the $10 \mathrm{~d}$ HRT, the gas production declined rapidly from the start, ceasing completely after the $5^{\text {th }}$ day. These results indicated that the bioreactors did not operate satisfactorily at HRTs shorter than $25 \mathrm{~d}$ under the 15$25^{\circ} \mathrm{C}$ diurnal temperature cycle. The failure of the digesters at 15 and $10 \mathrm{~d}$ HRTs is due to the combined effects of the low cyclic diurnal temperature and high loading rate.

The biogas production observed at the $20-40^{\circ} \mathrm{C}$ diurnal temperature cycle was characterized by rapid rise in production followed by a rapid decline, the shorter the retention time the more pronounced was the decline. This rapid rise in biogas production experienced at the beginning of each retention time can be attributed to the response of anaerobic bacteria to increased food supply as a result of the higher loading rate. Apparently, the acid forming bacteria responded faster to the increased loading rate. However, the accumulation of VFAs resulted in inhibition of the methane producing bacteria and hence reduction in

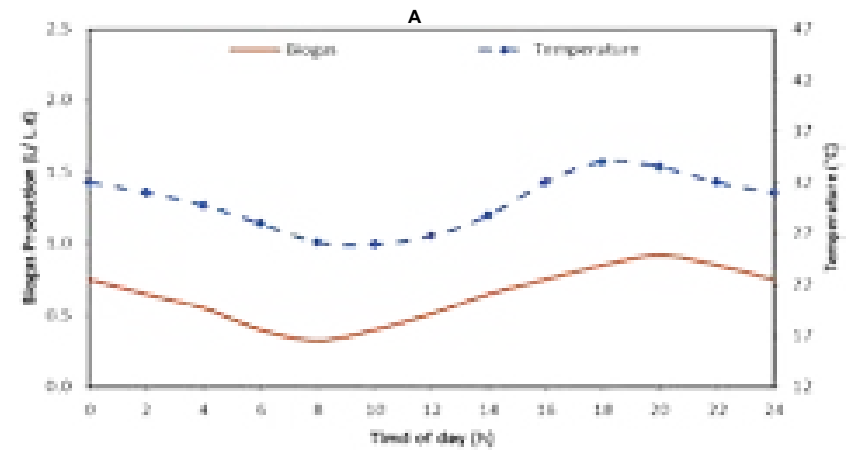

B

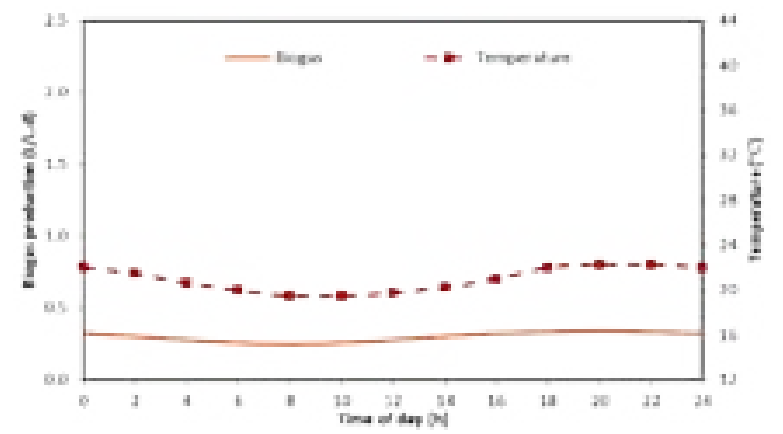

Figure 8: Diurnal variations in biogas production at the $25 \mathrm{~d} \mathrm{HRT}$. (a) $20-40^{\circ} \mathrm{C}$ Diurnal Temperature Cycle. (b) $15-25^{\circ} \mathrm{C}$ Diurnal Temperature Cycle.

\begin{tabular}{|c|c|c|c|c|}
\hline \multirow{2}{*}{ Diurnal Temperature Cycle $\left.\mathbf{(}^{\circ} \mathbf{C}\right)$} & \multirow{2}{*}{$\mathbf{H R T}(\mathbf{d})$} & \multicolumn{3}{|c|}{ Gas Composition } \\
\cline { 3 - 5 } & & $\begin{array}{c}\mathbf{C H}_{4} \\
(\mathbf{\%})\end{array}$ & $\begin{array}{c}\mathbf{C O}_{2} \\
\mathbf{( \% )}\end{array}$ & $\begin{array}{c}\text { Others } \\
\text { (\%) }\end{array}$ \\
\hline $20-40$ & 25 & $69.0 \pm 1.7$ & $25.8 \pm 1.5$ & 5.2 \\
\hline & 20 & $67.6 \pm 1.3$ & $28.6 \pm 2.3$ & 3.8 \\
\hline & 15 & $62.6 \pm 1.0$ & $37.3 \pm 1.0$ & 0.1 \\
\hline & 10 & $64.9 \pm 1.0$ & $34.9 \pm 1.0$ & 0.2 \\
\hline & 25 & $71.8 \pm 2.1$ & $25.3 \pm 1.0$ & 3.0 \\
\hline & 20 & $69.6 \pm 1.8$ & $27.3 \pm 1.0$ & 3.1 \\
\hline & 15 & $47.8 \pm 0.5$ & $44.0 \pm 1.2$ & 8.2 \\
\hline & 10 & $44.6 \pm 0.5$ & $43.6 \pm 1.8$ & 11.8 \\
\hline
\end{tabular}

*Each mean represents the average of 12 samples

${ }^{* *}$ Nitrogen, hydrogen sulphide, carbon monoxide, etc

Table 5: Biogas composition*.

biogas production. The higher rate of biogas production attained at a $20 \mathrm{~d}$ retention time indicated that at HRT longer than $20 \mathrm{~d}$, the reactors may have been underfed whereas at shorter retention times the reactors may have been overloaded.

In this study, higher biogas production was obtained with the $20 \mathrm{~h}$ HRT. However, literature reports on effect of HRT on biogas production vary depending on the type of waste and system used. Hossain et al. [35] noted that the biogas production increased in wastewaters as the HRT increased from 2 to $8 \mathrm{~h}$, but a further increase in the HRT from 8 to $14 \mathrm{~h}$ lead to a decrease in biogas production. Huang et al. [36] reported that the higher biogas yields were achieved at lower HRTs (8-12 h) during wastewater treatment. Rico et al. [22] noted that as the HRT decreased from 20 to $12.5 \mathrm{~d}$, the biogas production increased from 0.66 to $1.21 \mathrm{~m}^{3}$ during the anaerobic digestion of dairy manure.

In this study, higher biogas production was observed with higher temperatures (within the temperature range studied). However the 


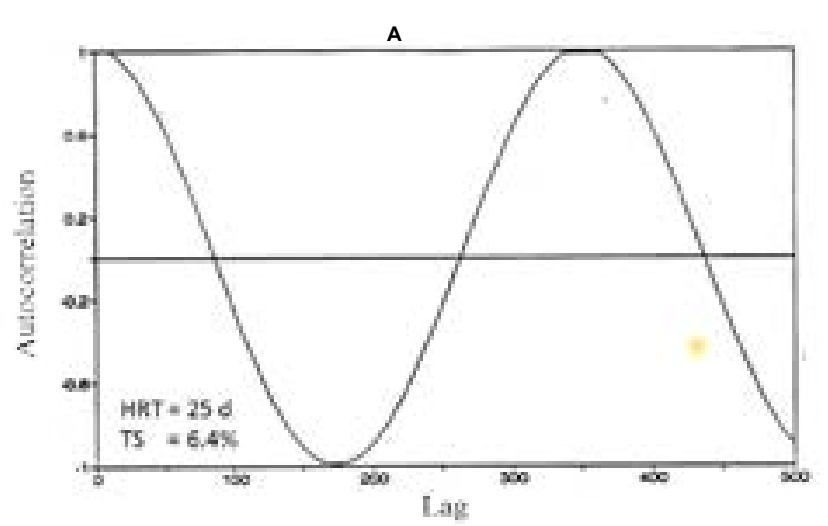

B

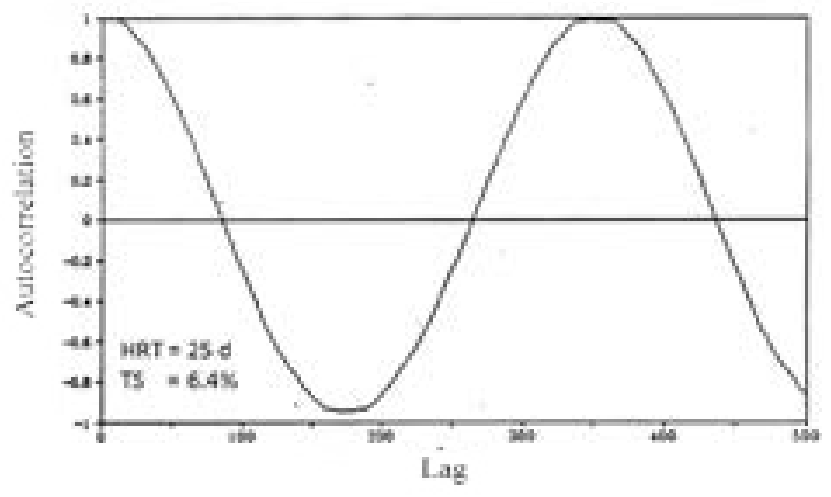

Figure 9: Typical correlogram of the diurnal biogas production rate $(\mathrm{HRT}=25$ days, TS $=6.4 \%$ ). (a) $20-40^{\circ} \mathrm{C}$ Diurnal Temperature Cycle. (b) $15-25^{\circ} \mathrm{C}$ Diurnal Temperature Cycle.

reports on the effect of temperature on biogas production vary. Hossain et al. [35] reported that biogas production increased as the temperature increased from 30 to $40^{\circ} \mathrm{C}$ during wastewater treatment, but further increase in temperature from 40 to $45^{\circ} \mathrm{C}$ resulted in a decrease in biogas production. Wu et al. [37] noted that the biogas production increased as the temperature increased from 20 to $40^{\circ} \mathrm{C}$ during anaerobic digestion of solid wastes and decreased with further increase in temperature to $45^{\circ} \mathrm{C}$ while a further increase to $55^{\circ} \mathrm{C}$ lead to a rapid increase in biogas production. Yu et al. [38] reported that more biogas production was achieved at temperatures of $55^{\circ} \mathrm{C}$ during anaerobic digestion of wastewaters than those obtained at $37^{\circ} \mathrm{C}$. Banerjee and Biswas [28] illustrated that during anaerobic digestion of wastes over the temperature range of 35 to $55^{\circ} \mathrm{C}$ maximum biogas production was achieved at $50^{\circ} \mathrm{C}$.

\section{Gas composition}

Diurnal variations in gas composition were observed at the all HRTs under the $20-40^{\circ} \mathrm{C}$ diurnal temperature cycle. Similar variations were observed at the $20 \mathrm{~d}$ HRT under the $15-25^{\circ} \mathrm{C}$ diurnal temperature cycle. A better gas quality (higher methane content) was obtained at all HRTs under the $20-40^{\circ} \mathrm{C}$ diurnal temperature cycle. Higher methane content was also obtained at the 25 and 20 HRTs under $15-25^{\circ} \mathrm{C}$ diurnal temperature cycle. Rises in the methane content of biogas as a result of a decrease in the bioreactor temperature have been reported by other researchers [34]. The increase in the quality of biogas is attributed to the raised solubility of carbon dioxide at the lower temperature cycle. Exceptions were observed with failed digesters. In stressed

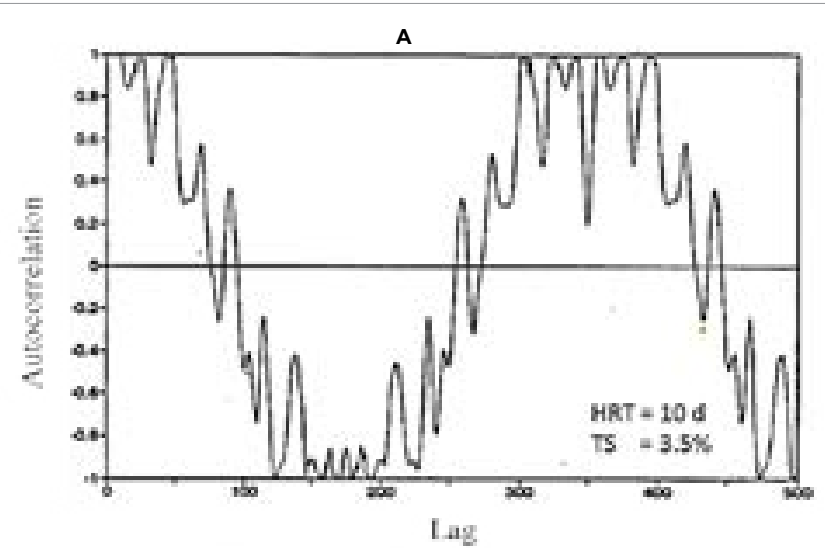

B

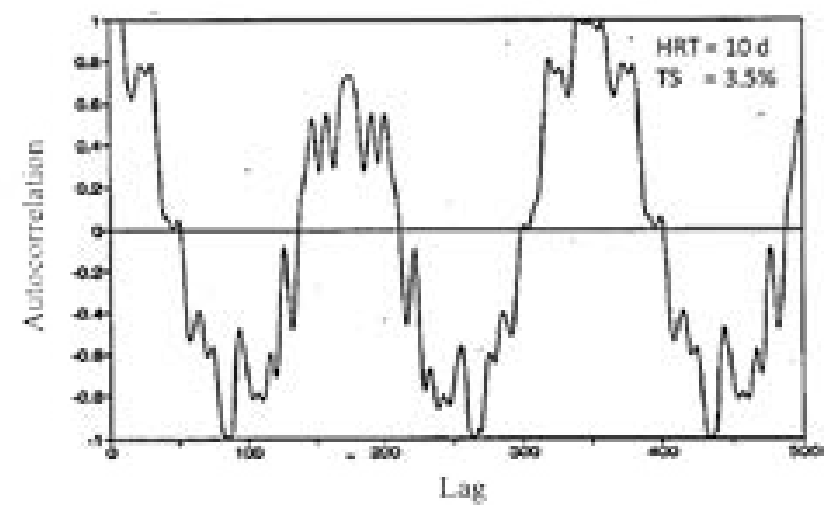

Figure 10: Typical correlogram of the diurnal biogas production rate $(H R T=10$ days, TS $=3.5 \%$ ). (a) $20-40^{\circ} \mathrm{C}$ Diurnal Temperature Cycle. (b) $15-25^{\circ} \mathrm{C}$ Diurnal Temperature Cycle.

methanogenic systems, hydrogen production and volatile fatty acids (more reduced than acetic acid such as propionate, butyrate etc.) have been reported to be produced in greater proportions [39].

The mean percentage of methane in the biogas ranged from 44.6 to $71.8 \%$, the carbon dioxide content ranged from 25.3 to $44.0 \%$ while the composition of the other gases (nitrogen, hydrogen sulphide etc.) ranged from 0.1 to $11.8 \%$. Methane values reported in the literature ranged from 40 to $75 \%[40,26,32-34]$. The observed values are, thus, within the range reported in the literature.

\section{Autocorrelation analysis}

A typical correlogram of diurnal biogas production is shown in Figure 9. Figure 9 a was obtained at 25 days HRT using manure of $6.4 \%$ TS content and the temperature cycle of $20-40^{\circ} \mathrm{C}$, while Figure $9 \mathrm{~b}$ was obtained using similar HRT and manure TS content but a temperature cycle of $15-25^{\circ} \mathrm{C}$. From the correlogram, it is seen that the diurnal biogas production rate predominantly followed a pattern similar to a sine wave. This pattern was observed with the operating temperature cycle of $20-40^{\circ} \mathrm{C}$ for all HRTs using the manure of $6.4 \%$ TS content and for the 25, 20 and 15 days HRTs using the manure of 3.5\% TS content. However, at the $15-25^{\circ} \mathrm{C}$ temperature cycle, the sinusoidal pattern was only observed at the 25 day HRT using the manure of $6.4 \%$ TS content.

The autocorrelation analysis shown in Figure 10 indicated that under low HRT (10 days) and low influent TS Concentration (3.5\%), the biogas production rate follows a sine wave sandwiched in some 


\begin{tabular}{|c|c|c|c|}
\hline $\begin{array}{l}\text { Temperature } \\
\text { Cycle }\left({ }^{\circ} \mathrm{C}\right)\end{array}$ & $\begin{array}{l}\text { Solids Content } \\
\text { (\%) }\end{array}$ & HRT (days) & $\begin{array}{l}\text { Sinusiodally } \\
\text { Periodic }\end{array}$ \\
\hline \multirow{8}{*}{$20-40$} & \multirow{4}{*}{6.4} & 25 & Yes \\
\hline & & 20 & Yes \\
\hline & & 15 & Yes \\
\hline & & 10 & Yes \\
\hline & \multirow{4}{*}{3.5} & 25 & Yes \\
\hline & & 20 & Yes \\
\hline & & 15 & Yes \\
\hline & & 10 & No \\
\hline \multirow{8}{*}{$15-25$} & \multirow{4}{*}{6.4} & 25 & Yes \\
\hline & & 20 & No \\
\hline & & 15 & No \\
\hline & & 10 & No \\
\hline & \multirow{4}{*}{3.5} & 25 & No \\
\hline & & 20 & No \\
\hline & & 15 & No \\
\hline & & 10 & No \\
\hline
\end{tabular}

*Each mean represents the average of 12 samples ${ }^{* *}$ Nitrogen, hydrogen sulphide, carbon monoxide, etc Table 6: Summary of Autocorrelation Analysis.

harmonics and noise. Various variants of Figure 10 were observed under the operating temperature cycle of $15-25^{\circ} \mathrm{C}$ for all retention times using the manure of $3.5 \%$ TS content and under the operating temperature cycle of $20-40^{\circ} \mathrm{C}$ with retention times of 10 to 20 days using the manure of $6.4 \%$ TS content. Furthermore, a similar correlogram was obtained under the retention time of 10 days using the manure of $3.5 \%$ TS concentration at the operating temperature cycle $20-40^{\circ} \mathrm{C}$. These results are summarized in Table 6.

The sinusoidal periodic variations in biogas production rates were obtained at almost all loading rates under the $20-40^{\circ} \mathrm{C}$ temperature cycle because the temperature of the reactor used in the study was designed to vary in a diurnally cyclic (sinusoidal) manner and microbial activity and gas production increases with increase in temperature. However, sinusoidal variations were not obtained under most of the loading rates at the temperature cycle of $15-25^{\circ} \mathrm{C}$ due to fact that the amplitude of diurnal fluctuation in reactor temperature was relatively so small and it was impossible to detect a true sine wave. At the higher loading rate, pure sinusoidal variation was not obtained probably because of the higher frequency of the feeding cycle (i.e. shorter feeding interval) as most of the evolved gases are scavenged from the headspace of the reactors and measured during the feeding process.

The result of the fast Fourier analysis on the diurnal biogas production data shown in Figures 11 and 12 showed that, where the diurnal biogas production cycle followed true sinusoidal relationships, the highest Fourier amplitude appeared to occur at a frequency of about $1.22 \times 10^{-5} \mathrm{~Hz}$. Thus, the dominant frequency of such gas production cycle lies at about $1.22 \times 10^{-5} \mathrm{~Hz}$. This frequency roughly corresponds to a period of 24 hours. However, when the biogas production cycle did not follow a true sinusoidal cycle, the dominant frequency (indicated by the highest Fourier amplitude) appeared to lie between 0.0013 and 0.0014 .

For the dominant frequency, the following regression equation, based on Fourier series, can be written to describe the diurnal variation in biogas production under diurnally cyclic temperature environment:

$$
\begin{aligned}
& \gamma_{t}=\gamma_{o}+\sum_{n=1}^{\infty}\left[a_{n} \cos (2 \pi n \varphi t)+b_{n} \cos (2 \pi n \varphi t)\right] \\
& \text { Where: }
\end{aligned}
$$
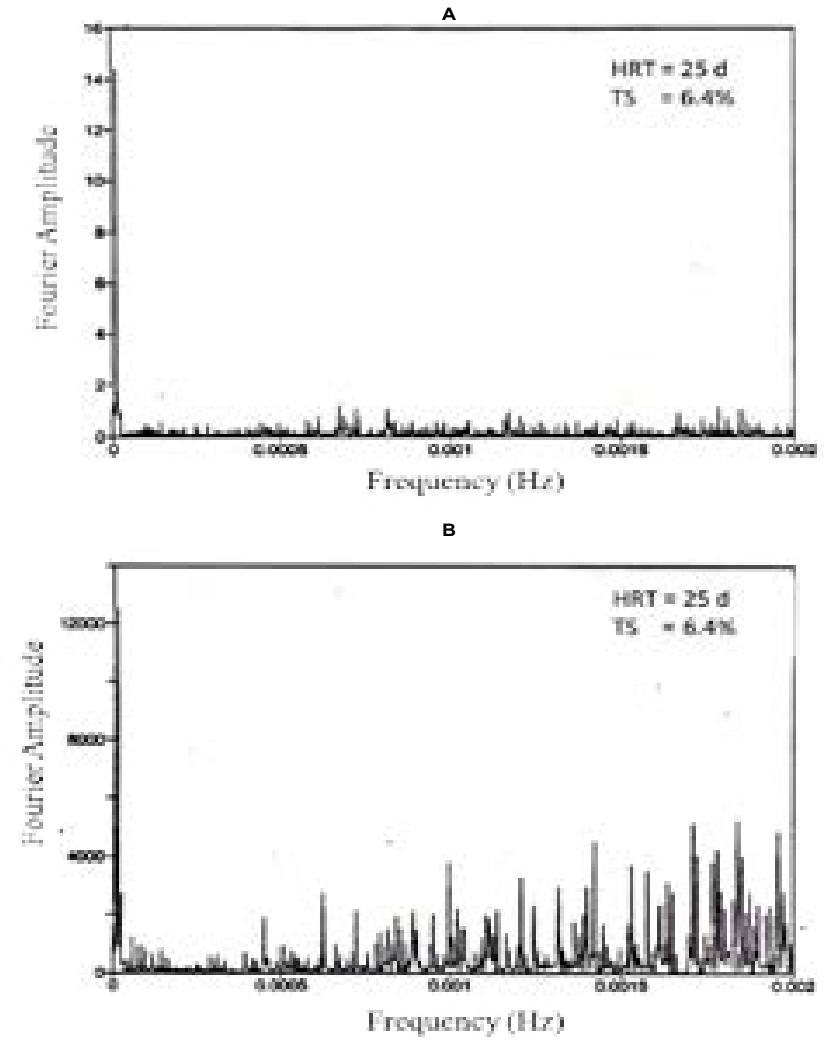

Figure 11: Typical discrete Fourier transform of the data on biogas production rate. (HRT $=25$ days, $\mathrm{TS}=6.4 \%$ ). (a) $20-40^{\circ} \mathrm{C}$ Diurnal Temperature Cycle. (b) $15-25^{\circ} \mathrm{C}$ Diurnal Temperature Cycle.

$\gamma_{\mathrm{t}}$ is the biogas production at a time $\mathrm{t}(\mathrm{L} / \mathrm{L} . \mathrm{d})$ (L/L.d)

$\gamma_{0}$ is the average biogas production per unit volume of reactor

$\varphi$ is the dominant frequency of the cycle $=1.22 \times 10^{-5}(\mathrm{~Hz})$

$a_{n}, b_{n}$ are Fourier coefficients.

The Fourier coefficients and mean daily biogas production rate can be obtained by regression analysis. These values will vary with operating conditions (cyclic temperature ranges and loading rates).

\section{Conclusion}

The effects of two diurnally cyclic temperature ranges $\left(20-40^{\circ} \mathrm{C}\right.$ and $\left.15-25^{\circ} \mathrm{C}\right)$ and four levels of hydraulic retention times $(25,20,15$, and $10 \mathrm{~d}$ ) on the performance of anaerobic reactors operated on screened dairy manure were evaluated. The reactor temperature exhibited a lag relative to the chamber air temperature. For the $20-40^{\circ} \mathrm{C}$ temperature cycle, the average lag period at the maximum and minimum chamber temperatures 3.75 and $4.37 \mathrm{~h}$, respectively. For the $15-25^{\circ} \mathrm{C}$ temperature cycle, the average lag periods at maximum and minimum chamber temperatures were 3.61 and $4.34 \mathrm{~h}$, respectively. The effluent solids content were not adversely affected by the reactor diurnally cyclic temperature. The effluent total solids and methane content of the biogas diurnally cyclic patterns were out of phase with the diurnally cyclic pattern of the reactor temperature by about 12 hours under most operating conditions. The reductions in total solids and methane yield 
Citation: Echiegu EA, Ghaly AE, Ramakrishnan VV (2013) Performance of Anaerobic Bioreactors under Diurnally Cyclic Air Temperatures: A Spectral Analysis Approach to Biogas Production. J Bioprocess Biotech 4: 143 doi: 10.4172/2155-9821.1000143
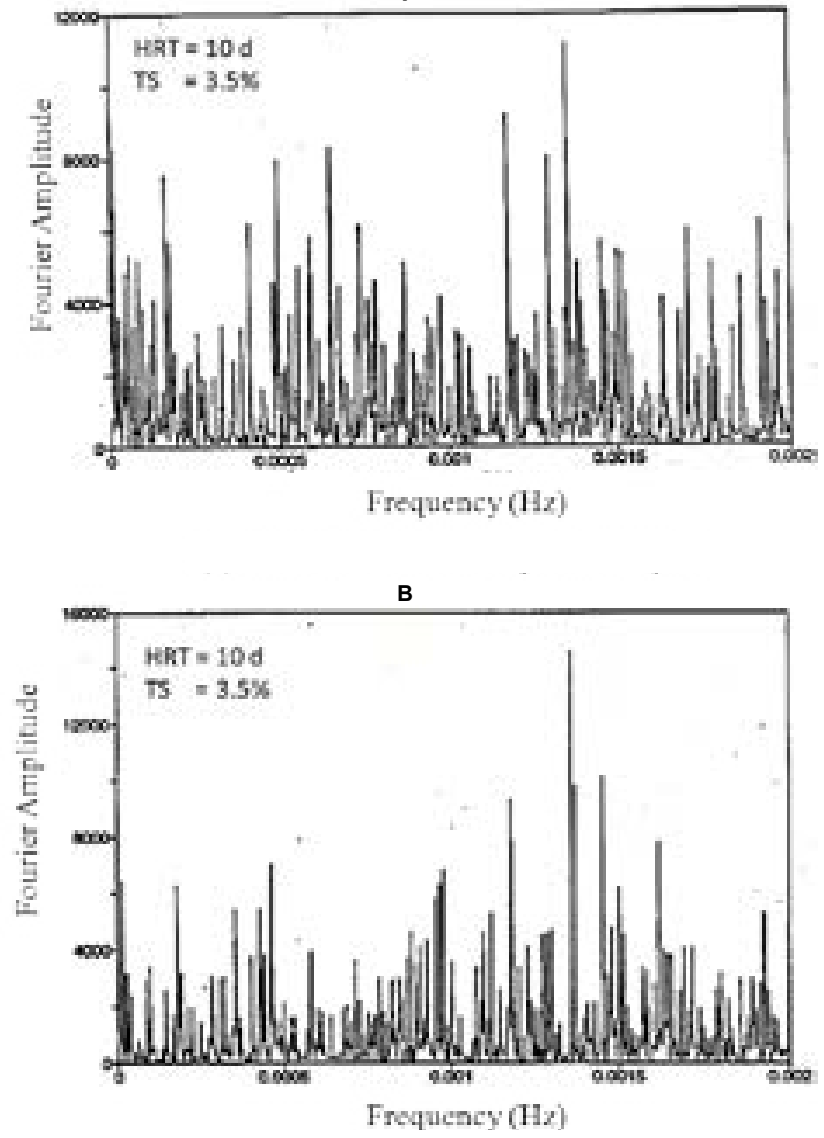

Figure 12: Typical discrete Fourier transform of the data on biogas production rate. (HRT $=10$ days, $\mathrm{TS}=3.5 \%$ ). (a) $20-40^{\circ} \mathrm{C}$ Diurnal Temperature Cycle. (b) $15-25^{\circ} \mathrm{C}$ Diurnal Temperature Cycle.

were all significantly affected by the diurnal temperature range and hydraulic retention time. Biogas production from a healthy digester operating under a diurnally cyclic temperature environment follow a sinusoidal pattern which can be described by a Fourier equation of the form: $\gamma_{t}=\gamma_{o}+\sum_{n=1}^{\infty}\left[a_{n} \cos (2 \pi n \varphi t)+b_{n} \cos (2 \pi n \varphi t)\right]$. However, where the operating conditions are not favourable, the production followed a sinusoidal pattern which may be embedded in some harmonic and noise.

\section{References}

1. El-Mashad HM, Zeeman G, Van Loon WKP, Bot GPA, Lettinga G (2004) Effect of Temperature and Temperature Fluctuation on Thermophilic Anaerobic Digestion of Cattle Manure. Bioresource Technol 95: 191-201.

2. Masse D, Gilbert Y, Topp E (2011) Pathogen Removal in a Farm-Scale Psychrophilic Anaerobic Digesters Processing Swine Manure. Bioresources Technol 102: 641-646.

3. Porpatham E, Ramesh A, Nagalingam B (2008) Investigation on the Effect of Concentration of Methane in Biogas when used as a Fuel for AaSpark Ignition Engine. Fuel 87: 1651-1659.

4. Burke DA (2001) Dairy Waste Anaerobic Digestion Handbook: Options for Recovering Beneficial Products From Dairy Manure.

5. Dieu TTM (2009) Food Processing and Food Waste. In C.J. Baldwin (Ed.), Sustainability in the Food Industry, Wiley-Blackwell, Ames, lowa.

6. Ghaly AE, Al-Hattab MT (2011) Effect of Diurnally Cyclic Temperature on the Performance of a Continuous Mix Anaerobic Digester. A J Biochem Biotechno 7: $146-162$.
7. Ghaly AE, Sadaka SS, Huzzaa A (2000) Kinetics of an Intermittent Flow Continuous Mix Anaerobic Reactor. Energ Sources 22: 525

8. Angelidaki I, Ahring BK (1994) Anaerobic Thermophilic Digestion of Manure at Different Ammonia Loads: Effect of Temperature. Water Res 28: 727-731.

9. Kim JK, Oh BR, Chun YN, Kim SW (2006) Effects of Temperature and Hydraulic Retention Time on Anaerobic Digestion of Food Waste. J Biosci Bioeng 102 328-332

10. Chae KJ, Jang A, Yim SK, Kim IS (2008) The Effects of Digestion Temperature and Temperature Shock on the Biogas Yields from the Mesophilic Anaerobic Digestion of Swine Manure. Bioresource Technol 99: 1-6.

11. Appels L, Degreve J, Van der Bruggen B, Van Impe J, Dewil R (2010) Influence of Low Temperature Thermal Pre-Treatment on Sludge Solubilisation Heavy Metal Release and Anaerobic Digestion. Bioresource Technol 101: 5743-5748.

12. Lianhua L, Dong L, Yongming S, Longlong M, Zhenhong Y, et. al., (2010) Effect of Temperature and Solid Concentration on Anaerobic Digestion of Rice Straw in South China. Int J Hydrogen Energ 35: 7261-7266.

13. Gustin S, Marinsek-Logar R (2011) Effect of Ph, Temperature and Air Flow Rate on the Continuous Ammonia Stripping of the Anaerobic Digestion Effluent. Process Saf Environ 89: 61-66.

14. Echiegu EA (1992) Performance of a Continuous-Mix Anaerobic Reactor Operating on Dairy Manure Under Two Diurnal Temperature Ranges. Unpl. PhD thesis. Technical University of Nova Scotia.

15. Ghaly AE, Echiegu EA, Ben-Hassan RM (1992) Performance Evaluation of a Continuous Mix Anaerobic Reactor Operating of Dairy Manure under Diurnally Cyclic Temperature. ASAE paper No 92-6025. Presented at the Summer meeting of ASAE, Charlotte, North Carolina, USA.

16. Davis JC (1973) Statistics And Data Analysis In Geology. John Willey and Sons, NY.

17. American Public Health Association (APHA). 1985. Standard Methods for the Examination of Water and Wastewater, 16th ed. APHA, Washington, D.C.

18. Wilkie AC, Castro HF, Cubinski KR, Owens JM, Yan SC (2004) Fixed-Film Anaerobic Digestion of Slushed Dairy Manure after Primary Treatment: Wastewater Production and Characterisation. Biosystems Eng 89: 457-471.

19. Elango D, Pulikesi M, Baskaralingam P, Ramamurthi V, Sivanesan S (2007) Production of Biogas from Municipal Solid Waste with Domestic Sewage. J Hazard Mater 141: 301-304.

20. Ribas MM, Barana AC (2003) Start-Up Adjustment of a Plug-Flow Digester for Cassava Wastewater (Manipueira) Treatment. Scientia Agricola 60: 223-229.

21. Umana O, Nikolaeva S, Sanchez E, Borja R, Raposo F (2008) Treatment of Screened Dairy Manure by Upflow Anaerobic Fixed Bed Reactors Packed with Waste Tyre Rubber and a Combination of Waste Tyre Rubber and Zeolite: Effect of the Hydraulic Retention Time. Bioresources Technol 99: 7412-7417.

22. Rico C, Rico JL, Tejero I, Munoz N, Gomez B (2011) Anaerobic Digestion of the Liquid Fraction of Dairy Manure in Pilot Plant for Biogas Production: Residual Methane Yield of Digestate. Waste Manage 31: 2167-2173.

23. Ghaly AE, Echiegu E (1993) Kinetics of a Continuous Flow No-Mix Anaerobic Reactor. Energ Source 15: 433-449.

24. De la Rubia MA, Perez M, Romero LI, Sales D (2002) Anaerobic Mesophilic and Thermophilic Municipal Sludge Digestion. Chem Biochem Eng Q 16: 119-124.

25. Trazcinski AP, Stuckey DC (2011) Parameters Affecting the Stability of the Digestate from a Two-Stage Anaerobic Process Treating the Organic Fraction of Municipal Solid Waste. Waste Manage 31: 1480-1487.

26. Converse JC, Zeikus JG, Graves RC, Evans GW (1977) Anaerobic Degradation of Dairy Manure Under Mesophilic And Thermophilic Temperatures. Transactions of the ASAE 20: 336-340.

27. Colmenarejo MF, Sanchez E, Bustos A, Garcia G, Borja R (2004) A Pilot-Scale Study of Total Volatile Fatty Acids Production by Anaerobic Fermentation of Sewage in Fixed-Bed and Suspended Biomass Reactors. Process Biochem 39: $1257-1267$.

28. El-Mashad HM, Van Loon WKP, Zeeman G (2003) A Model of Solar Energy Utilisation in the Anaerobic Digestion of Cattle Manure. Biosys Eng 84: 231-238.

29. Elefkiniotis P, Oldham WK (1994) Effect of HRT on Acidogenic Digestion of Primary Sludge. J Environ Eng 120: 645-660. 
Citation: Echiegu EA, Ghaly AE, Ramakrishnan VV (2013) Performance of Anaerobic Bioreactors under Diurnally Cyclic Air Temperatures: A Spectral Analysis Approach to Biogas Production. J Bioprocess Biotech 4: 143 doi: 10.4172/2155-9821.1000143

30. Maharaj I, Elefsiniotis P (2001) The Role of HRT and Low Temperature on the Acid-Phase Anaerobic Digestion of Municipal and Industrial Wastewaters. Bioresource Technol 76: 191-197.

31. Choorit W, Wisarnwan P (2007) Effect of Temperature on the Anaerobic Digestion of Palm Oil Mill Effluent. Electron J Biotechnol 10: 376-385.

32. Jeyanayagam SS, Collins ER (1984) Weed Seed Survival in a Dairy Manure Anaerobic Digester. Transactions of the ASAE 27: 1518-1523.

33. Lo KV, Liao PH (1986) Thermophilic Anaerobic Digestion of Screened Dairy Manure Using A Two-Phase Process. Energ Agr 5: 249-255.

34. Peck MW, Skillon JM, Hawkes FR, Hawkes DL (1986) Effect of Temperature Shock Treatments on the Stability of Anaerobic Digesters Operated on Separated Cattle Slurry. Water Res 20: 453-462.

35. Hossain M, Anantharaman N, Das M (2009) Anaerobic Biogas Generation from Sugar Industry Wastewaters in Three-Phase Fluidized-Bed Bioreactor. Indian J Chem Technol 16: 58-64.
36. Huang Z, Ong SL, Ng HY (2011) Submerged Anaerobic Membrane Bioreactor for Low-Strength Wastewater Treatment: Effect of HRT and SRT on Treatment Performance and Membrane Fouling. Water Res 45: 705-713.

37. Wu M, Sun K, Zhang $Y$ (2006) Influence of Temperature Fluctuation on Thermophilic Anaerobic Digestion of Municipal Organic Solid Waste. J Zhejiang Univ Sci B 7: 180-185.

38. Yu HQ, Fang HHP, Gu GW (2002) Comparative Performance of Mesophilic and Thermophilic Acidogenic Upflow Reactors. Process Biochem 38: 447-454.

39. Mclnerney JM, Bryant MP (1981) Basic Principles of Bioconversion in Anaerobic Digestion and Methanogenesis. Biomass Conversion Process for Energy and Fuel 277-296.

40. Hills DJ, Stephens JR (1980) Solar Energy Heating of Dairy-Manure Anaerobic Digesters. Agr Wastes 2: 103-118. 